\title{
Winter Sub-Freezing Periods and Significant Thaws in the Boreal Forest Region of Central North America
}

\author{
THOMAS W. SCHMIDLIN' and REBECCA A. ROETHLISBERGER ${ }^{1}$
}

(Received 9 June 1992; accepted in revised form 7 October 1992)

\begin{abstract}
Winter daily maximum temperatures were examined for 56 sites in northern portions of Ontario, Michigan, Wisconsin, and Minnesota over the period 1960-88. The longest sub-freezing period of winter averaged 20-30 days in the southern portion of the region, 30-40 days around Lake Superior, and 90-100 days in extreme northwestern Ontario. These are twice as long as sub-freezing periods at similar latitudes in eastern Canada. The sub-freezing period is shortened by about one week along the shores of the Great Lakes. There is annual spatial correlation of the longest sub-freezing period, indicating regional synoptic-scale control. The late 1970s had the longest sub-freezing periods but no significant linear trend was found in lengths of sub-freezing periods. The average date of the first significant thaw $\left(>10^{\circ} \mathrm{C}\right.$ ) ranged from early March in the south to late April in the north and is delayed 1-2 weeks along the shores of the Great Lakes.
\end{abstract}

Key words: winter, freezing temperature, boreal forest, Canada, Great Lakes

RÉSUMÉ. De 1960 à 1988, on a mené une étude sur les températures quotidiennes maximales en hiver à 56 emplacements situés dans des régions septentrionales de 1'Ontario, du Michigan, du Wisconsin et du Minnesota. La plus longue période de gel hivernal persistant durait en moyenne de 20 à 30 jours dans la partie méridionale de la région, de 30 à 40 jours autour du lac Supérieur, et de 90 à 100 jours dans la partie la plus au nord-ouest de l'Ontario. Ces durées sont deux fois plus longues que les périodes de gel persistant aux mêmes latitudes dans l'est du Canada. La période de gel persistant est réduite d'environ 1 semaine le long des rives des Grands Lacs. Il existe une corrélation spatiale annuelle de la période de gel persistant la plus longue, ce qui indique un contrôle régional à échelle synoptique. La fin des années 1970 comptait les périodes de gel persistant les plus longues, mais on n'a pas trouvé de tendance linéaire significative dans la durée des périodes de gel persistant. La date moyenne du premier dégel notable $\left(>10^{\circ} \mathrm{C}\right)$ allait de début mars dans le Sud à fin avril dans le Nord et était repoussée de 1 à 2 semaines le long des rives des Grands Lacs.

Mots clés : hiver, température inférieure à $0^{\circ} \mathrm{C}$, forêt boréale, Canada, Grands Lacs

Traduit pour le journal par Nésida Loyer.

\section{INTRODUCTION}

The seasonal snow cover that envelops the subarctic boreal forests for 4-7 months each winter is an important component of boreal ecosystems (Pruitt, 1957, 1960). This long-lasting snowpack develops because temperatures are below freezing most of the winter - the period that Courtin et al. (1991) called the "nival period" of the boreal forest year. Air temperatures that are consistently below freezing allow only small, gradual changes in snowpack structure and in the subnivean environment. Temperatures above $0^{\circ} \mathrm{C}$ during winter cause surface melt and rapidly alter the snowpack, changing the albedo, depth, density, stratigraphy, and thermal conductivity of snow (Gilbert and McKenna Neuman, 1988). Temperatures above freezing in winter may also reduce coldhardiness of trees and lead to damage in subsequent cold waves (Innes, 1992). The recent concern over global warming has increased the interest in monitoring ecologically significant indices of climatic change.

Winter temperatures, especially fluctuations across the freezing point, affect the growth, metamorphism, and decay of snowpacks. The depth and density of a snowpack and its spatial variability affect the subnivean environment of small mammals (Marchand, 1982; Auerbach and Halfpenny, 1991). Winter thaws reduce the effective insulation of the snowpack and are hazardous to small mammals of the boreal forest that depend on snow cover to protect them from extreme temperatures, chilling winds, and radiation loss (Courtin et al., 1991; Auerbach and Halfpenny, 1991). Ruffed grouse (Bonasa umbellus) mortality has been reported from ice layers on snow (McGowan, 1969) and snow quality is important to the winter survival of ptarmigan (Lagopus leucurus) (Braun and Schmidt, 1971). Spatial variability in snow covers, as controlled by microclimate and regional climate, also affects the winter environment at the ground/snow interface and the upper soil layers, with implications for plant community dynamics and soil formation (Auerbach and Halfpenny, 1991; Schaetzl and Isard, 1991).

Snowpack characteristics also control the movements, distribution, and health of large mammals. White-tailed deer (Odocoileus virginianus) move easily through deep snow when a firm surface crust provides footing but tire quickly when the crust is too weak to support their weight (Verme, 1968; Verme and Ozoga, 1971). Movement of these deer is greatly restricted at snow depths over $40 \mathrm{~cm}$ (Kelsall, 1969) and they are vulnerable to starvation and wolf predation (Nelson and Mech, 1986). Variable winter temperature patterns and snow conditions may also segregate white-tailed deer from moose (Alces alces) populations (Telfer, 1967, 1970) and cause movement of moose among various forest types (Peek, 1971). Mule deer (Odocoileus hemionus) survive winter well in snow depths up to $45 \mathrm{~cm}$ if the snow remains dry and powdery. However, they are weakened or forced to move to other areas if winter thaws result in crusts in the snowpack (Gilbert et al., 1970). Caribou (Rangifer acticus) of northern Saskatchewan forests avoid areas with snow over $60 \mathrm{~cm}$ deep or density greater than $200 \mathrm{~kg} \cdot \mathrm{m}^{-3}$ (Pruitt, 1959).

Winter thermal threshold parameters, such as the duration of sub-freezing temperatures, return periods of extreme temperatures, winter thaws, and freeze dates, serve as 
important indicators of the thermal climate of a region (Suckling, 1986; Schmidlin, 1988; Gilbert and McKenna Neuman, 1988; Watkins, 1991). Schindler et al. (1990) report that climatic warming in the boreal forest region of Manitoba has been associated with more forest fires, less snow cover, earlier melt of snow, earlier ice-out on lakes, and deeper thermoclines in lakes. However, Plantico et al. (1990) have shown slight cooling trends during 1948-87 in mean annual, winter, and summer temperatures in the northern Great Lakes region of the United States.

To address these issues, we summarize the climatology of winter sub-freezing periods, winter thaws $\left(>0^{\circ} \mathrm{C}\right)$, and the first major spring thaw $\left(>10^{\circ} \mathrm{C}\right)$ in the boreal forests of central North America (Fig. 1). This climatic perspective on the winter thermal regime of the boreal forest is useful in analyses of present boreal ecosystems. This perspective will also provide a benchmark against which the present climate and its impacts can be compared to future changes as they are observed or anticipated.

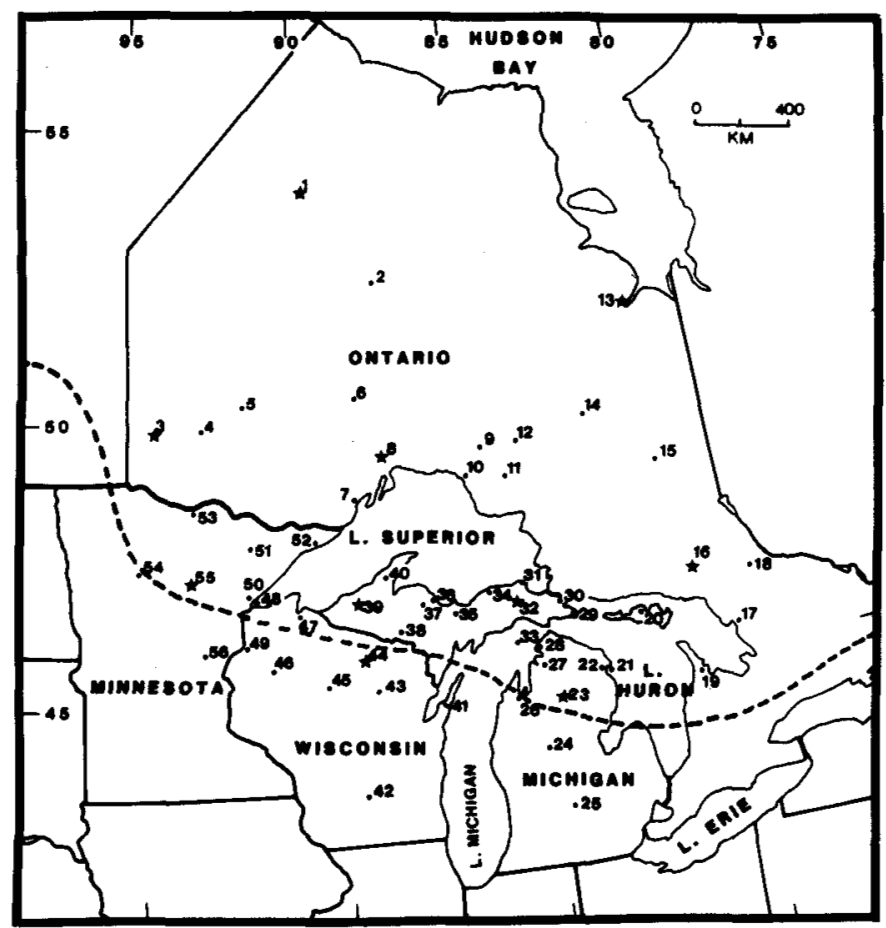

FIG. 1. The southern margin of the boreal forest of central North America (dashed line) (from Shelford, 1963:121), sites examined in this research (numbered dots and stars), and sites examined for time trends (stars). The spruce-balsam climax of the boreal forest occurs north of Lake Superior, while the forest south of Lake Superior is a pine-hemlock transition to the deciduous forest (Shelford, 1963:143). 1) Big Trout Lake. 2) Lansdowne House. 3) Kenora. 4) Dryden. 5) Sioux Lookout. 6) Armstrong. 7) Thunder Bay. 8) Cameron Falls. 9) Manitouwadge. 10) Marathon. 11) White River. 12) Hornepayne. 13) Moosonee. 14) Kapuskasing. 15) Timmins. 16) Sudbury. 17) Parry Sound. 18) North Bay. 19) Wiarton. 20) Gore Bay. 21) Alpena. 22) Alpena Airport. 23) Grayling. 24) Evart. 25) Lansing. 26) Traverse City. 27) Boyne City. 28) Cross Village. 29) De Tour. 30) Sault Ste. Marie. 31) Whitefish Point. 32) Newberry. 33) Beaver Island. 34) Grand Marais. 35) Chatham. 36) Marquette. 37) Ishpeming. 38) Crystal Falls. 39) Bergland Dam. 40) Houghton. 41) Sturgeon Bay. 42) Baraboo. 43) Antigo. 44) Long Lake. 45) Medford. 46) Rice Lake. 47) Ashland. 48) Danbury. 49) Duluth Harbor. 50) Duluth Airport. 51) Tower. 52) Grand Marais. 53) International Falls. 54) Bemidji. 55) Grand Rapids. 56) Mora.

\section{METHODS}

Daily maximum temperatures at 56 weather stations in the northern portions of Michigan, Wisconsin, Minnesota, and Ontario with at least 25 years of data for the period 1960-88 were analyzed (Fig. 1). These stations were in the federal climate networks and data were archived by the U.S. National Climatic Data Center and the Canada Climate Centre. The weather stations were mostly located over sod in clearings outside of the forest, as prescribed by federal standards. Average winter daily maximum temperatures measured in these open environments may be $1-2^{\circ} \mathrm{C}$ warmer than within a conifer forest (Ozoga, 1968). Average January daily maximum temperatures range from $-2^{\circ} \mathrm{C}$ at the southeastern margin of the study area to $-20^{\circ} \mathrm{C}$ in extreme northwestern Ontario. Average annual snowfall is $150-250 \mathrm{~cm}$ over most of the region, with local averages over $500 \mathrm{~cm}$ on high terrain south and east of Lake Superior. Snow covers the ground for 80-150 days annually south of Lake Superior and 150-200 days north of Lake Superior (Potter, 1965). Winter maximum snow depths are in the range of $50-100 \mathrm{~cm}$, although depths over $200 \mathrm{~cm}$ have been recorded.

The longest period with temperatures continuously below $0^{\circ} \mathrm{C}$ was determined by visual examination for each winter at each site. In addition, the occurrence of thaws $\left(>0^{\circ} \mathrm{C}\right.$ and $>10^{\circ} \mathrm{C}$ ) was noted. The average and extreme lengths of the longest sub-freezing period of winter were determined, along with the average date of the first significant thaw $\left(>10^{\circ} \mathrm{C}\right)$ and the empirical probability of a significant thaw during selected months. Several pairs of stations representing the Great Lakes shore and nearby inland environments were available to assess the effect of the lakes. Ten stations with good spatial representation and with little missing data were chosen for an analysis of spatial correlation and trends in the longest sub-freezing period during the $1960-88$ period (Fig. 1). A much longer (1911-88) record for Newberry, Michigan, was examined for time trends. The relationship between the longest sub-freezing period each winter and mean January temperature for that winter was examined for National Weather Service offices at Marquette, Michigan, and Duluth, Minnesota. Selected results were mapped by manually fitting lines to the data points with consideration for terrain and the Great Lakes.

\section{RESULTS AND DISCUSSION}

The average length of the longest sub-freezing period of winter is 20-30 days at the southern margin of the study area, 30-50 days in the vicinity of Lake Superior, and 90 to over 100 days along the shores of Hudson Bay and in far northwestern Ontario (Fig. 2). The dominant pattern is for increasing lengths of sub-freezing periods northward, with the colder winter climate at higher latitudes. There is also a weak trend to longer sub-freezing periods toward the west. The more frequent thaws in the eastern portion of the region may be due to the influence of warm sectors in cyclonic disturbances of the "Midwest" storm track (Richman et al., 1991) moving northeastward through the Great Lakes region in winter. The result of this winter storm track is a more 


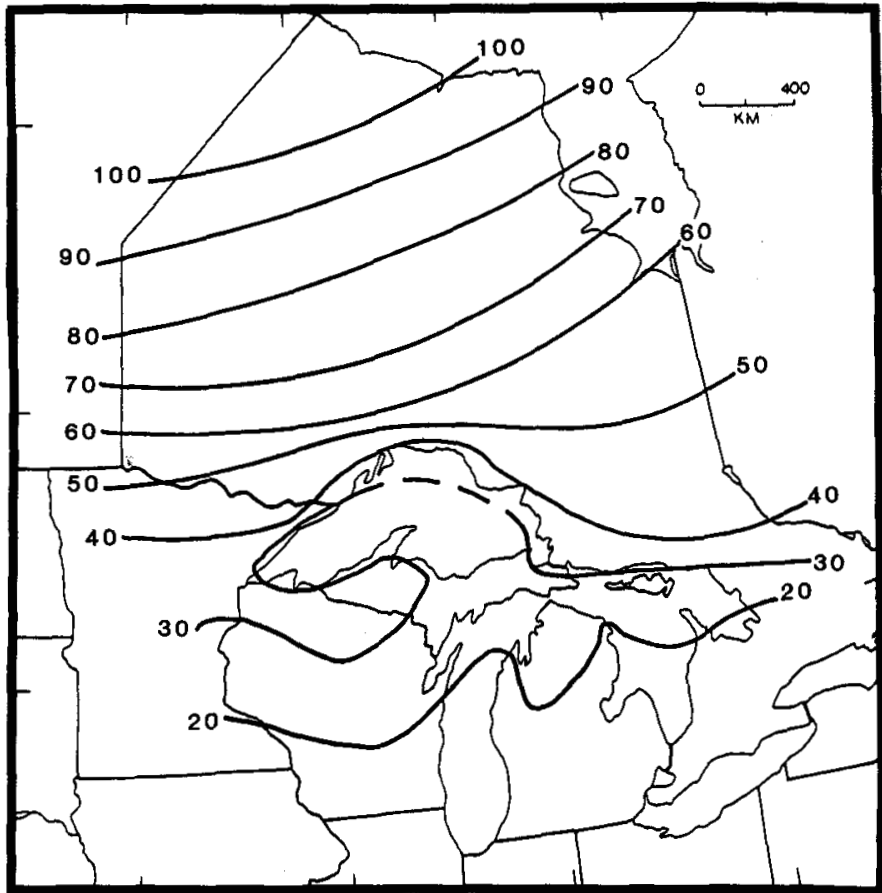

FIG. 2. Average length in days of the longest period of winter with temperatures $<0^{\circ} \mathrm{C}$.

continental winter climate in Minnesota and northwestern Ontario, persistent cold, and fewer winter thaws than east of the storm track. Increasing continentality has been shown to be associated with longer sub-freezing periods in Newfoundland and Labrador (Schmidlin, 1988). The average sub-freezing period of 70-100 days in northern Ontario is about twice as long as the average of 35-50 days at similar latitudes in the more maritime boreal forest region of eastern Canada in Labrador (Schmidlin, 1988). While both regions have extensive winter snow cover, the more frequent winter thaws in Labrador give different characteristics in the snowpacks of that region than in the continental interior, where winter thaws are less common.

The Great Lakes exert a significant influence on the pattern shown in Figure 2 by decreasing the length of the longest sub-freezing period along the shores of the lakes. Lake Superior and the northern portions of Lake Michigan and Lake Huron are deep and do not freeze over entirely in most winters. Ice forms along the shoreline in late December and January and progresses to mid-lake in February and March (Saulesleja, 1986; Assel, 1990). The average extent of ice cover on Lake Superior is just $10 \%$ in January, about $40 \%$ in February and March, and 17\% in April. Sub-freezing periods that are established during December and early January are often broken by a thaw along the milder lake shores, where open water warms the air to about $5^{\circ} \mathrm{C}$ above the inland temperatures (Saulesleja, 1986). For example, the longest sub-freezing period averaged 31 days at Duluth Harbor on the Lake Superior shore but 36 days at Duluth Airport, $10 \mathrm{~km}$ inland. Of the seven years when the longest sub-freezing period was more than 10 days shorter at the harbor station than at the airport, five involved December thaws at the harbor that did not occur at the airport. A similar difference existed between the 25-day average at Marquette and the 31-day average $15 \mathrm{~km}$ inland at Ishpeming. The sharpest gradient of the winter sub-freezing period is in the region immediately north of Lake Superior. The average longest sub-freezing period increases from 30 days at the shore to 60 days about $50 \mathrm{~km}$ inland, as the maritime influence of the lake diminishes and elevation increases northward.

The extreme longest sub-freezing period during 1960-88 was 50-60 days at the southern margin of the study area, 70-90 days on the north shore of Lake Superior, and 140 days in far northwestern Ontario (Fig. 3). These values are much greater than those reported for the northefn Great Lakes region during the 1950 s by Bryson and Hare (1974) and indicate the severity of winters during the late 1970 s in the region. A pattern of increasing values northwestward is again evident in Figure 3, as in Figure 2, with a sharp gradient north of Lake Superior and along the Minnesota-Ontario border.

Annual correlation of the longest sub-freezing period was significantly different from zero $(p<0.05)$ among ten stations examined. This may indicate that regional winter weather patterns, such as persistent polar anticyclones or cyclonic disturbances causing thaws, generally affect large parts of the region simultaneously. Regional correlation of the annual longest sub-freezing period was also reported for Newfoundland and Labrador (Schmidlin, 1988). There was significant $(p<0.05)$ negative annual correlation $(-0.57$ and -0.52$)$ between mean January temperature and the longest subfreezing period at Marquette and Duluth, as found also for Newfoundland (Schmidlin, 1988).

No linear trend $(R=0.02)$ during $1960-88$ was found in the annual longest sub-freezing period pooled among ten stations (Fig. 4). This is not surprising given the relatively short period of data and large inter-annual variability.

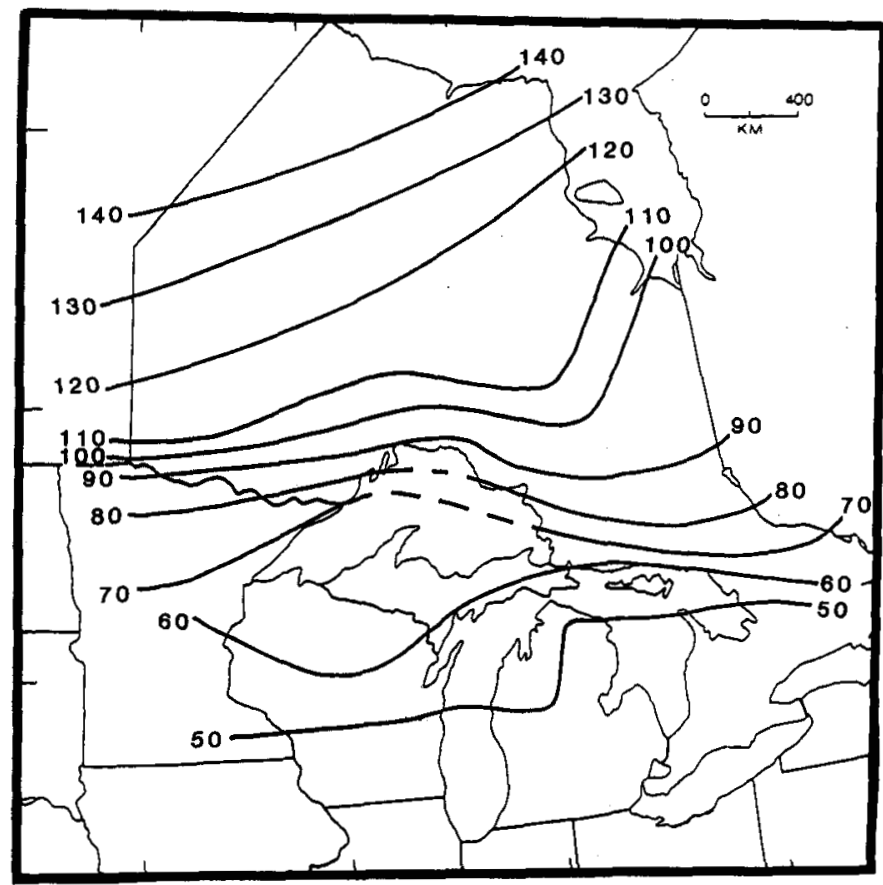

FIG. 3. The longest sub-freezing period in days during 1960-88. 


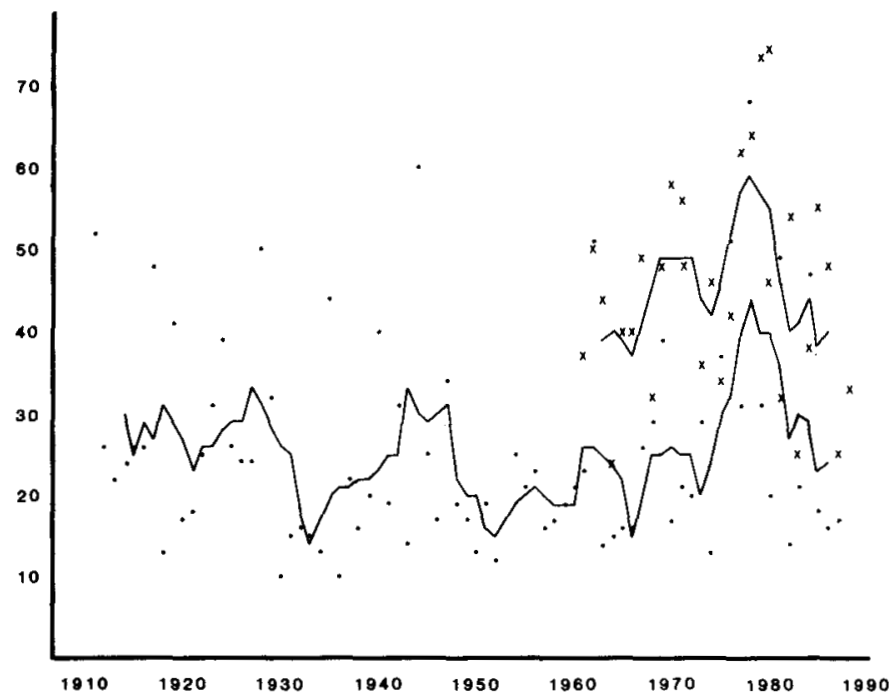

FIG. 4. The longest sub-freezing period of winter for 1911-88 at Newberry, Michigan (dots), and pooled values for 1960-88 at ten sites (x). Solid lines are 5-year running means of the data plotted on the center year.

Similarly, no linear trend $(R=0.0001)$ was found in the 76-year record (1911-88) at Newberry, Michigan, but 5-year running means show that the sub-freezing periods were relatively short in the early 1930 s and the 1950 s and were long in the 1920s, 1940s and 1970s (Fig. 4). The peak of long sub-freezing periods in the late $1970 \mathrm{~s}$ was unprecedented in the 76-year record at Newberry and reflects the severity of those winters in central North America (Diaz and Quayle, 1980).

The average date of the first significant thaw $\left(>10^{\circ} \mathrm{C}\right)$ is before 10 March along the southern margin of the study area, near 1 April along the shores of Lake Superior, and after 20 April in far northwest Ontario (Fig. 5). The date of the first $10^{\circ} \mathrm{C}$ is delayed along the lake shores, where cold water

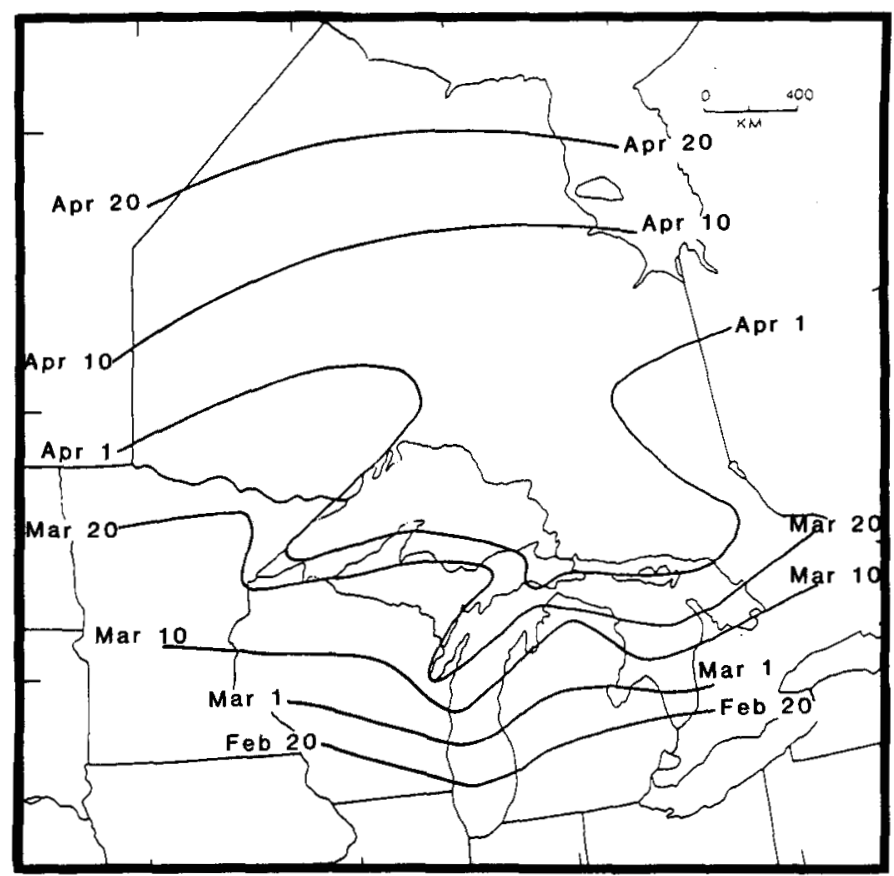

FIG. 5. Mean date of the first $10^{\circ} \mathrm{C}$ temperature of spring. and ice persist well into spring. Average surface water temperatures of Lake Superior and northern portions of Lake Michigan and Lake Huron are below $2^{\circ} \mathrm{C}$ in April (Saulesleja, 1986) and shore ice may remain into May (Assel, 1990). Thus, the average date of the first $10^{\circ} \mathrm{C}$ is 8 April at Whitefish Point, Michigan, on the south shore of Lake Superior and 6 April at Moosonee, Ontario, $600 \mathrm{~km}$ to the north. Among local examples of the effects of the lakes, the average date of the first $10^{\circ} \mathrm{C}$ temperature is 4 March at the Alpena, Michigan, airport, but it is 18 March at the Lake Huron shore, $8 \mathrm{~km}$ to the east. Average dates for the first $10^{\circ} \mathrm{C}$ temperature are 4 March at Cross Village, Michigan, and 30 March on Beaver Island, $25 \mathrm{~km}$ out in northern Lake Michigan.

Temperatures of $10^{\circ} \mathrm{C}$ were not observed during January at the stations adjacent to northern Lake Michigan or Lake Huron or from Lake Superior northward (Fig. 6a). The probability that there will be one or more days with a $10^{\circ} \mathrm{C}$ temperature increases to about $10 \%$ in February near southern Lake Superior, but these temperatures do not occur north of the lake in February. The probability of a significant thaw during February is $20-40 \%$ in the central Great Lakes region. The probability of a $10^{\circ} \mathrm{C}$ temperature increases to $70-90 \%$ south of Lake Superior during March (Fig. 6b). However, the cold water of the lake reduces the probability of a significant thaw in March to less than 50\% north of the lake. The patterns in Figure $6 \mathrm{~b}$ show that significant March thaws move into northern Ontario from the west in the KenoraDryden area and from the east in the North Bay-Timmins area but are prevented from entering the region north of Lake Superior by the cold waters and lake ice. The probability of reaching $10^{\circ} \mathrm{C}$ in March is $43 \%$ at Sault Ste. Marie but $61 \%$ at Timmins, $300 \mathrm{~km}$ to the northeast; $31 \%$ at Grand Marais, Minnesota, but $36 \%$ at Kenora, $400 \mathrm{~km}$ to the northwest.

In summary, the winter thermal regime of the boreal forest, including sub-freezing periods and intervening thaws, controls the development and evolution of the winter snowpack and affects winter ecosystems within and above the snow. The average length of the longest sub-freezing period of winter is 30-100 days across the boreal forest region of central North America. The shorter sub-freezing periods to the south and east mean that winter thaws remove shallow snowpacks, exposing the ground surface to subsequent cold temperatures, and thaws that do not remove the snowpack will create ice layers and other metamorphic products in the snowpack. The longer sub-freezing periods of the north and northwest preserve a deeper persistent snowpack without the mid-winter development of ice layers and related features. There is regional correlation and synoptic-scale control of the longest sub-freezing period of winter, making it useful as an indicator of changes in climate and ecosystems. No linear trend exists in the data but periods of persistently short or long subfreezing periods were evident, notably the long sub-freezing periods in the late 1970s. The Great Lakes exert a maritime influence, shortening the longest sub-freezing period by several days near their shores, but this mid-continent region has much longer winter sub-freezing periods than similar latitudes in maritime eastern Canada in Labrador. The first significant thaw $\left(>10^{\circ} \mathrm{C}\right)$ occurs in early March in the south and late April in the north, with a delay of one to two weeks along the Great Lakes shores. 

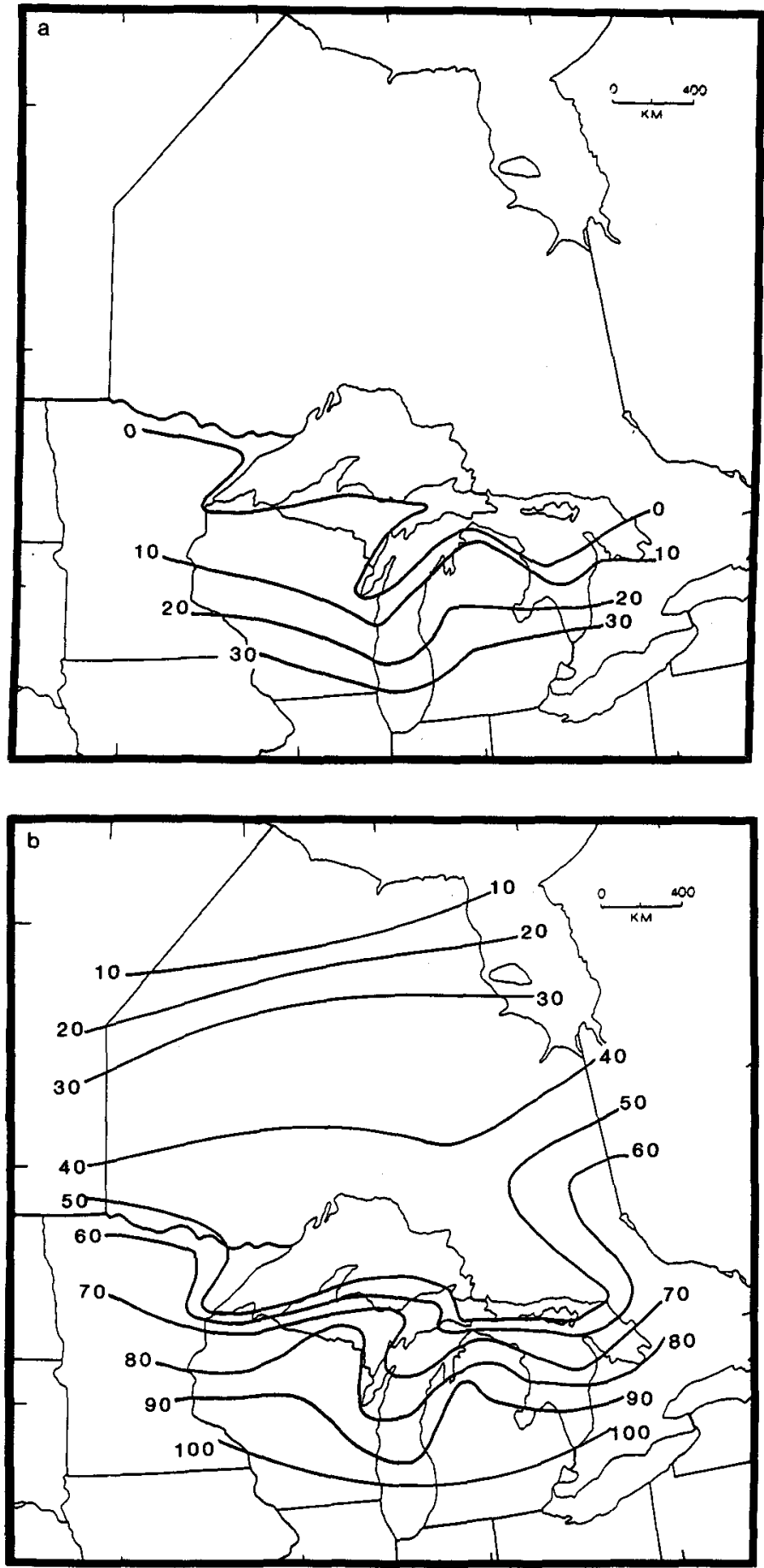

FIG. 6. Percent probability of a significant thaw $\left(10^{\circ} \mathrm{C}\right)$ during a) January and b) March.

\section{ACKNOWLEDGEMENTS}

Funding for this research and our travel to the Circumpolar Ecosystems in Winter II Symposium and Arctic Workshop was provided by the Department of Geography, the Office of Research and Sponsored Programs, and the Graduate Student Senate at Kent State University.

\section{REFERENCES}

ASSEL, R.A. 1990. An ice cover climatology for Lake Erie and Lake Superior for the winter seasons 1897-98 to 1982-83. International Journal of Climatology 10:731-748.
AUERBACH, N.A., and HALFPENNY, J.C. 1991. Snowpack and the subnivean environment for different aspects of an open meadow in Jackson Hole, Wyoming, U.S.A. Arctic and Alpine Research 23:41-44.

BRAUN, C.E., and SCHMIDT, R.K., Jr. 1971. Effects of snow and wind on wintering populations of white-tailed ptarmigan in Colorado. In: Haugen, A.O., ed. Proceedings of the Symposium on Snow and Ice in Relation to Wildlife and Recreation, Ames: Iowa State University. 238-250.

BRYSON, R.A., and HARE, F.K. 1974. Climates of North America. Vol. 11. In: World survey of climatology. Amsterdam: Elsevier Scientific Publishing.

COURTIN, G.M., KALLIOMAKI, N.M., HILLIS, T., and ROBITAILLE, R.L. 1991. The effect of abiotic factors on the overwintering success in the meadow vole, Microtus Pennsylvanicus: Winter redefined. Arctic and Alpine Research 23:45-52.

DIAZ, H.F., and QUAYLE, R.G. 1980. An analysis of the recent extreme winters in the contiguous United States. Monthly Weather Review 108:687-699.

GILBERT, P.F., WALLMO, O.C., and GILL, R.B. 1970. Effect of snow depth on mule deer in Middle Park, Colorado. Journal of Wildife Management 34:15-23.

GILBERT, R., and McKENNA NEUMAN, C. 1988. Occurrence and potential significance of warm weather during winter in the eastern Canadian Arctic. Arctic and Alpine Research 20:395-403.

INNES, J.L. 1992. Forest declines. Progress in Physical Geography 16:1-64.

KELSALL, J.P. 1969. Structural adaptations of moose and deer for snow. Journal of Mammalogy 50:302-310.

MARCHAND, P.J. 1982. An index for evaluating the temperature stability of a subnivean environment. Journal of Wildlife Management 46:518-520.

McGOWAN, J.D. 1969. Starvation of Alaskan ruffed and sharp-tailed grouse caused by icing. Auk 86:142-143.

NELSON, M.E., and MECH, L.D. 1986. Relationship between snow depth and gray wolf predation on white-tailed deer. Journal of Wildlife Management 50:471-474.

OZOGA, J.J. 1968. Variations in microclimate in a conifer swamp deeryard in northern Michigan. Journal of Wildlife Management 32:574-585.

PEEK, J.M. 1971. Moose-snow relationships in northeastern Minnesota. In: Haugen, A.O., ed. Proceedings of the Symposium on Snow and Ice in Relation to Wildlife and Recreation. Ames: Iowa State University. 39-49.

PLANTICO, M.S., KARL, T.R., KUKLA, G., and GAVIN, J. 1990. Is recent climate change across the United States related to rising levels of anthropogenic greenhouse gases? Journal of Geophysical Research 95:16617-16637.

POTTER, J.G. 1965. Snow cover. Climatological Studies No. 3. Toronto: Canada Department of Transport, Meteorological Branch.

PRUITT, W.O., Jr. 1957. Observations on the bioclimate of some taiga mammals. Arctic 10:130-138.

.1959 . Snow as a factor in the winter ecology of the barren ground caribou. Arctic 12:159-179.

1960. Animals in the snow. Scientific American 202:61-68.

RICHMAN, M.B., LAMB, P.J., and ANGEL, J.R. 1991. Multivariate statistical analysis of precipitation associated with North American winter storm tracks. Preprints of the Fifth Conference on Climate Variations. Boston: American Meteorological Society. 47-53.

SAULESLEJA, A. 1986. Great Lakes climatological atlas. Downsview: Atmospheric Environment Service, Environment Canada.

SCHAETZL, R.J., and ISARD, S.A. 1991. The distribution of spodosol soils in southern Michigan: A climatic interpretation. Annals of the Association of American Geographers 81:425-442.

SCHINDLER, D.W., BEATY, K.G., FEE, E.J., CRUIKSHANK, D.R., DeBRUYN, E.R., FINDLAY, D.L., LINSEY, G.A., SHEARER, J.A., STAINTON, M.P., and TURNER, M.A. 1990. Effects of climatic warming on lakes in the central boreal forest. Science 250:967-970.

SCHMIDLIN, T.W. 1988. The longest sub-freezing period in Newfoundland winters. Climatological Bulletin 22:35-42.

SHELFORD, V.E. 1963. The ecology of North America. Urbana: University of Illinois Press.

SUCKLING, P.W. 1986. Fluctuations of last spring freeze dates in the southeastern United States. Physical Geography 7:239-245.

TELFER, E.S. 1967. Comparison of moose and deer winter range in Nova Scotia. Journal of Wildlife Management 31:418-425. 
1970. Winter habitat selection by moose and white-tailed deer. Journal of Wildlife Management 34:553-559.

VERME, L.J. 1968. An index of winter weather severity for northern deer. Journal of Wildlife Management 32:566-574.

VERME, L.J., and OZOGA, J.J. 1971. Influence of winter weather on white-tailed deer in upper Michigan. In: Haugen, A.O., ed. Proceedings of the Symposium on Snow and Ice in Relation to Wildlife and Recreation. Ames: Iowa State University. 16-28.

WATKINS, C. 1991. The annual period of freezing temperatures in central England: 1850-1989. International Journal of Climatology 11:889-896. 